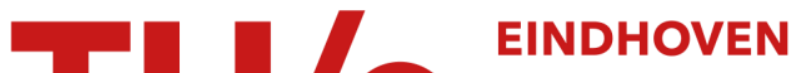 UNIVERSITY OF TECHNOLOGY
}

\section{The biomechanics of Wolff's law: recent advances}

\author{
Citation for published version (APA): \\ Prendergast, P. J., \& Huiskes, H. W. J. (1995). The biomechanics of Wolff's law: recent advances. Irish Journal \\ of Medical Science, 164(2), 152-154. https://doi.org/10.1007/BF02973285
}

DOI:

10.1007/BF02973285

Document status and date:

Published: 01/01/1995

\section{Document Version:}

Publisher's PDF, also known as Version of Record (includes final page, issue and volume numbers)

\section{Please check the document version of this publication:}

- A submitted manuscript is the version of the article upon submission and before peer-review. There can be important differences between the submitted version and the official published version of record. People interested in the research are advised to contact the author for the final version of the publication, or visit the $\mathrm{DOI}$ to the publisher's website.

- The final author version and the galley proof are versions of the publication after peer review.

- The final published version features the final layout of the paper including the volume, issue and page numbers.

Link to publication

\section{General rights}

Copyright and moral rights for the publications made accessible in the public portal are retained by the authors and/or other copyright owners and it is a condition of accessing publications that users recognise and abide by the legal requirements associated with these rights.

- Users may download and print one copy of any publication from the public portal for the purpose of private study or research.

- You may not further distribute the material or use it for any profit-making activity or commercial gain

- You may freely distribute the URL identifying the publication in the public portal.

If the publication is distributed under the terms of Article 25fa of the Dutch Copyright Act, indicated by the "Taverne" license above, please follow below link for the End User Agreement:

www.tue.nl/taverne

Take down policy

If you believe that this document breaches copyright please contact us at:

openaccess@tue.nl

providing details and we will investigate your claim. 


\title{
The Biomechanics of Wolff's Law: Recent Advances
}

\author{
P. J. Prendergast* ${ }^{\dagger}$, R. Huiskes ${ }^{\dagger}$ \\ *Bioengineering Research Center, Department of Mechanical Engineering, Trinity College, Dublin 2, Ireland. \\ ${ }^{+}$Biomechanics Section, Institute of Orthopaedics, University of Nijmegen, 6500HB Nijmegen, The Netherlands.
}

\begin{abstract}
"Wolff's law" is widely known in orthopaedics. For example, it is often said that load bearing devices, such as joint replacement prostheses or external fixators, cause bone to adapt according to Wolff's law. In this article, the scientific basis for Wolff's law is described in the light of recently developed biomechanical theories of bone behaviour.
\end{abstract}

\section{Introduction}

Julius Wolff died in 1902 by which time his name had become synonymous with the function-form relationship in bone. He held a Personal Chair in Surgery at the University of Berlin and it was there, in 1892, that he published his treatise Das Gesetz der Transformation der Knochen ("The Law of Bone Transformation")" "This work eventually made him famous, but at the time he was known mostly for his passionate lecturing, his aggressive style and his prodigious capacity for publication. He was so successful that time has ensured him of the greatest honour science can bestow - a law in his name.

Wolff's law is, in fact, a series of observations which imply the following conclusion: bone adapts its external shape and internal structure in response to the mechanical forces it is required to support. Wolff found evidence for his law by examination of pathologically healed fractures: an untreated fernoral neck fracture, for example, heals at an incorrect angle generating a new external shape and internal trabecular structure.

Wolff was also interested in the biological process governing adaptation. He proposed the* bone adapts by "interstitial bone formation" - that is by creating new bone particles between old ones. His contemporaries, lead by Roux ${ }^{[2]}$, argued an opposite thesis of "bone remodelling" whereby resorption of aged or deteriorated bone is followed by formation of new tissue in the resorption space. It turns out that Roux was right, but this was not proven until more recent times ${ }^{[3]}$.

Recent research on Wolff's law has focused on obtaining the biomechanical signa! which drives the adaptation process. The signal is associated with either (a) microdamage in the bone or (b) strain in the mineralised bone tissue. A physiological paradigm for Wolff's law, which involves no loss of generality, is to assume that bone has "mechano-receptors" or "sensors" distributed throughout the tissue. The mechano-receptors sense the biomechanical signal and emit a chemical (or electrical) stimulus which generates a new activity pattern for the osteoclasts (bone resorbing cells) and osteoblasts (bone forming cells). As the bone changes shape in response to the new forces, the stimulus emitted by the mechanoreceptors reduces until the bone assumes a suitable shape to carry the new load.
What are the Sensors? ...

The biomechanical signal must be sensed at a microstructural level by cells. Plausible candidates for this are; (i) osteocytes, which are contained in lacunae and connected to the bone surface via a dense canalicular network ${ }^{[4]}$, or (ii) bone lining cells which cover quiescent bone surfaces (Haversian canals, trabecular surfaces etc.) ${ }^{15]}$.

... and how are the Sensors Activated?

There are two possible mechanisms relating sensor activation to mechanical loads;

(i) Deformations of the lacunae under load. This causes fluid flow in the lacunae which stimulates the osteocytes ${ }^{14]}$.

(ii) Microdamage in the form of inter-constituent microcracks. Microcracks stimulate the sensors, either by altering the local tissue deformation ${ }^{[3]}$, or by changing the biochemical environment in the tissue by release of growth factors ${ }^{[4,6]}$.

Both of these mechanisms have been investigated using a computer simulation technique called Finite Elemont Analyșis'. Investigations of mechanism (i) have shown that a distribution strain-sensitive osteocytes, each having its own region of influence, is consistent with trabecular bone formation ${ }^{[7]}$. To study mechanism (ii), we carried out a computer simulation of a piece of cortical bone as it undergoes microdamage in the form of microcracks at the 'cement-line' connecting the osteon to the interstitial matrix ${ }^{[8]}$. Substantial strain changes are predicted for both the osteocyte cells in the lacunae and for the bone lining cells on the Haversian canal wall. Therefore, the cell population in the bone would sense a reduction in strain around a microcrack. This result supports the hypothesis that microdamage activates resorption as a first step in bone remodelling ${ }^{[5]}$.

\section{Motive for the Adaptation Process}

We conclude from the above that damage accumulation or strain changes are sensed locally by certain cells.

1 Finite element analysis is a computer-based method for determination of the physical behaviour of structures. The structure is divided into simple parts (called elements) whose behaviour can be straightforwardly described. Using special mathematical techniques of matrix algebra and local co-ordinate descriptions for the elements, the behaviour of the complete structure can be determined when the elements are re-assembled. 


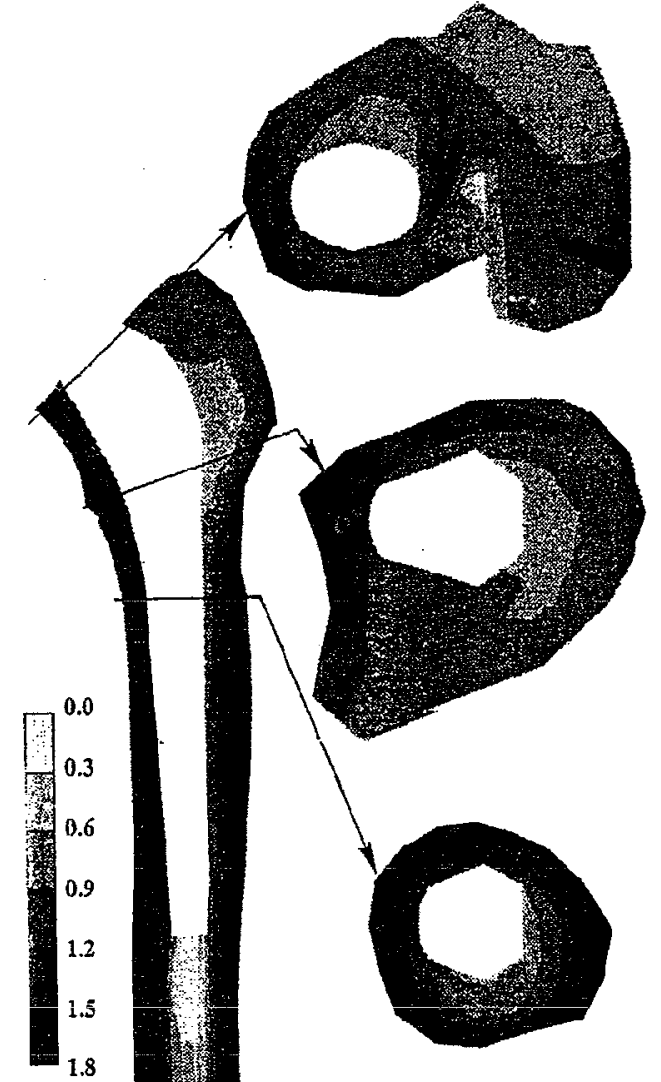

Initial Density

(a)

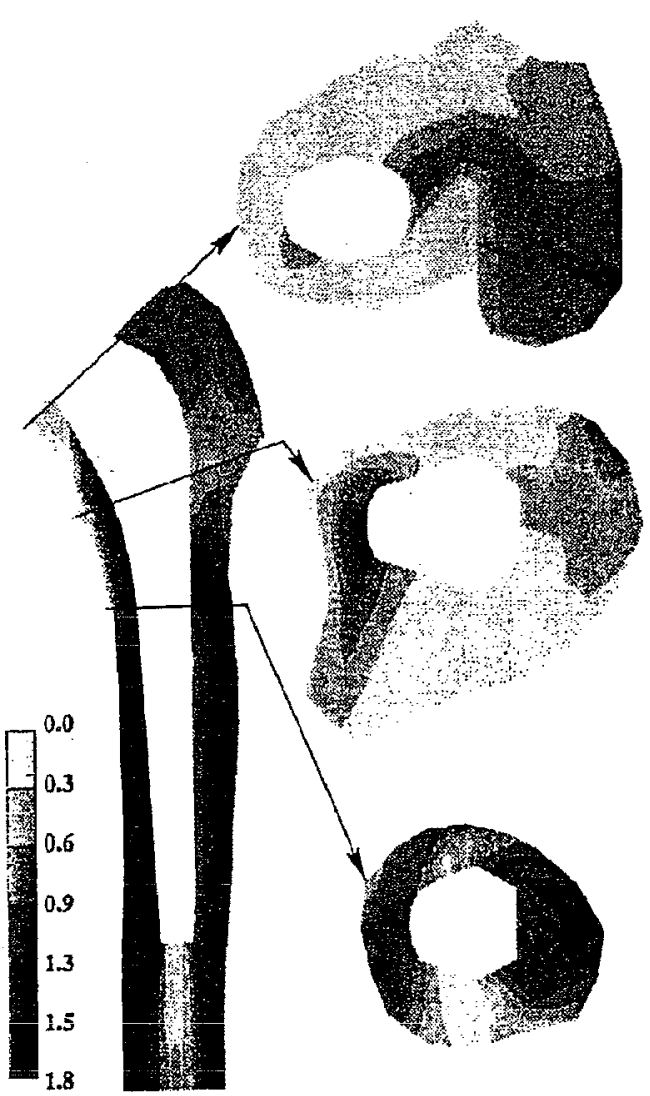

Final Density (Titanium stem)

(b)

Figure 1 - Computer simulation of bone adaptation around the femoral component of a hip replacement prosthesis. (a) Initial (immediate post-operative) density distributions $\left(\mathrm{gr} / \mathrm{cm}^{3}\right)$ in the proximal femur, as determined from CT scans. (b) Final density distribution $\left(\mathrm{gr} / \mathrm{cm}^{3}\right.$ ) after remodelling is complcted around the titanium stem as predicted by the compuler simulation, from ${ }^{\| 11}$ with permission.

Independently of any central control, these cells produce a bone suitable for its mechanical function; an objective is targeted and the cells 'strive' to achieve it.

For a microdamage signal, microcracks will continue to accumulate if the repair rate is insufficient to mend the damage as it is formed (such a phenomenon can cause stress fractures). In this case, the motive for adaptation is to re-obtain an acceptable amount of microdamage in the bone tissue. In engineering terms, one would say that the adaptation process maintains an efficient "factor-ofsafety" for the bone. Too high a factor-of-safety would require too large a bone whereas too low a factor-ofsafety would predispose an easy bone fracture ${ }^{\text {91. Lee et }}$ al. ${ }^{[10]}$ report experiments designed to investigate this relationship between microdamage accumulation and Wolff's law.

The process of Wolff's law has also been described as one of maintaining a physiologically acceptable strain pattern in the mineralised bonc matrix. Extensive testing of this description has been carried out by comparing computer predictions with clinical observations ${ }^{[1]}$. To show the power of this approach, an example of these predictions is given for a femur with a hip prosthesis (Fig.
1). Calcar resorption and a certain amount of hypertrophy distal to the prosthesis tip are predicted. Follow-up studies show that certain prosthesis designs can provoke this kind of reaction.

\section{Concluding Remarks}

It is more than a century since Wolff proposed his law of bone adaptation. Over that century, many observations in orthopaedics were explained by it. Improved methods of analysis have allowed us to unravel some of these observations and describe them biomechanically. It is now state-of-the-art to predict bone reactions around implants using computerized simulations. If this could be routinely achicved, then Wolff's law could be used to test new orthopaedic procedures before animal trials are undertaken. Such pre-clinical assessments may facilitate improved innovation of orthopaedic implants in the future $^{[12]}$.

\section{Acknowledgements}

This work was partly funded by Forbairt under the Strategic Research Programme and by the Commission of the European Communities. 


\section{References}

1. Wolff, J. Das Gesetz der Transformation der Knochen. A. Hirschwald: Berlin, 1892. Translated by Manquet, P. and Furlong, $R$. as The Law of Bone Remodelling. S pringer: Berlin, 1986.

2. Roux, W. Der züchtende Kampf der Theile, oder die 'Theilauslese' im Organismus (The struggle of the components within organisms). Wilhelm Englemann: Leipzig. 1881

3. Frost, H. M. Intermediary Organization of the Skeleton. CRC Press: Boca Raton, FL. 1986.

4. Lanyon, L. E. Osteocytes, strain detection, bone modelling and remodelling. Calcif. Tissue Int. 53 (Suppl. 1), S102S107, 1993.

5. Martin, R. B., Burr, D. B. Structure, Function and Adaptation of Compact Bone. Raven Press: New York, 1989.

6. Eriksen, E. F., Kassem, M. The cellulat basis of bone remodelling. Sandoz J. Med. Sci. 1992: 31, 45-57.
7. Mullender, M.G., Huiskes, R. A proposal for the regulatory mechanism of Wolff's law. J. Orthop. Res. (in press).

8. Prendergast, P. J., Huiskes, R. Mathematical modelling of microdamage in bone remodelling and adaptation. Chapter 19 In Bone Structure and Remodelling (Weinans, $H$. and Odgaard, A., eds.), World Scientific: Singapore, 1995.

9. Prendergast, P. J., Taylor, D. Prediction of bone adaptation using damage accumulation. J. Biomechanics 1994: 27, $1067-76$.

10. Lee, T. C., Mulville, J. P., Prendergast, P. J., Taylor, D. A model for the study of bone adaptation under altered load. In Transactions of the Second World Congress of Biomechanics: Amsterdam, Vol. II, p.239, 1994.

11. Huiskes, R., Weinans, H., Van Rietbergen, B. The relationship between stress shielding and bone resorption around total hip stems and the effects of flexible materials. Clin. Orthop. rel. Res. 1992: 274, 124-34.

12. Huiskes, R. Failed innovation in total hip replacement. Diagnosis and proposals for a cure. Acta Orthop. Scand. 1993: 64, 699-716. 